\title{
Iranian households expenditure pattern between 2013 and 2018 with emphasis on health care expenditure trends after Iran's health transformation plan (IHTP)
}

\author{
Mohammad Hossein Mehrolhassani ${ }^{1,2}$,Vahid Yazdi-Feyzabadi ${ }^{2,3}$,Ali Darvishi, ${ }^{4,5}$, Mohammadreza Sheikhy- \\ Chaman $^{6}$ \\ 1. Associate Professor, Health Services Management Research Center, Institute for Futures Studies in Health, Kerman \\ University of Medical Sciences, Kerman, Iran. ORCID: 0000-0002-2412-9277. \\ 2. Department of Health Management, Policy and Economics, Faculty of Management and Medical Information Sciences, \\ Kerman University of Medical Sciences, Kerman, Iran. \\ 3. Assistant Professor, Social Determinants of Health Research Center, Institute for Futures Studies in Health, Kerman \\ University of Medical Sciences, Kerman, Iran. ORCID: 0000-0002-8009-470X. \\ 4. Ph.D. Candidate, Students' Scientific Research Center (SSRC), Tehran University of Medical Sciences (TUMS), Tehran, \\ Iran., (Corresponding Author), Tel: 021-88989129, Email: alidarvishieco@ gmail.com, ORCID: 0000-0002-3173-9065. \\ 5. Modeling in Health Research Center, Institute for Futures Studies in Health, Kerman University of Medical Sciences, \\ Kerman, Iran. 0000-0002-3173-9065 \\ 6. Ph.D Student, Department of Health Economics, School of Health Management and Information Sciences, Iran University \\ of Medical Sciences, Tehran, Iran. ORCID: 0000-0002-7381-2005
}

\begin{abstract}
Background and Aim: Estimation and analysis of household expenditure patterns can always be considered as one of the most suitable tools to raise awareness of policy makers. The aim of this study was to investigate shares of different parts of Iranian household expenditures with emphasis on health care cost.

Material and Methods: This descriptive study was conducted by using raw data about households expenditure obtained from Iran statistical center (1392-1396). The household expenditure patterns of 6 subcategories were analyzed. The share of health care expenditures on the basis of income quintiles were reviewed before and after the Iran's health hransformation program (1392-1396). Excel 2010 and Stata 14 softwares were used for data analysis and drawing the charts.

Results: In urban households, the cost of housing and in rural households cost of food and clothing had the highest shares in household expenditures. The costs of education in both groups of urban and rural households had the lowest share in household expenditures. The share of health care expenditures in urban and rural households has increased in the study years and after IHTP in all quintiles. Except for the fifth quintile in urban households, the results were similar.
\end{abstract}

Conclusion: The results showed significant alterations in the household expenditure pattern. The shares of health care expenditure after the IHTP has increased, indicating that the program has not been successful to achieve the goal of household financial protection.

Keywords: Expenditure pattern, Health care expenditures, Iran's health transformation program, Income quintiles

Received: May 15, 2019

Accepted: Oct 3, 2020

How to cite the article: Mohammad Hossein Mehrolhassani,Vahid Yazdi-Feyzabadi,Ali Darvishi, Mohammadreza Sheikhy-Chaman. Iranian households expenditure pattern between 2013 and 2018 with emphasis on health care expenditure trends after Iran's health transformation plan (IHTP). SJKU. 2021;26(3):117-128.

Copyright $\odot 2018$ the Author (s). Published by Kurdistan University of Medical Sciences. This is an open access article distributed under the terms of the Creative Commons Attribution-Non-Commercial License 4.0 (CCBYNC), where it is permissible to download, share, remix, transform, and buildup the work provided it is properly cited. The work cannot be used commercially without permission from the journal 


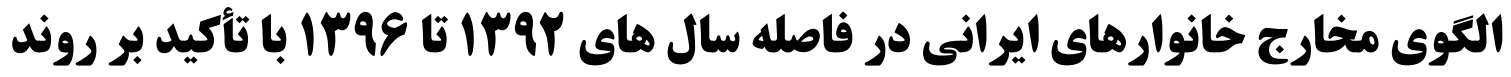 مخارج سلامت بعد از طرح تحول سلامت
}

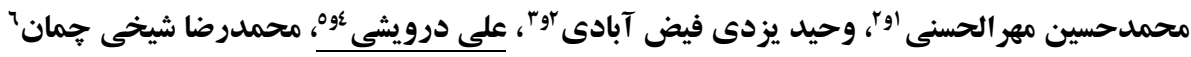

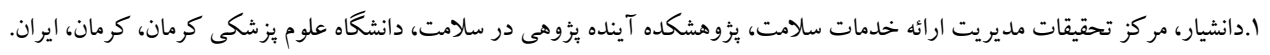 \\ كد ار كيد:

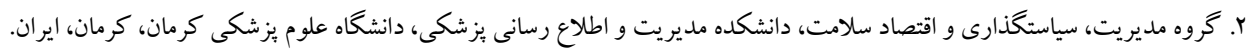

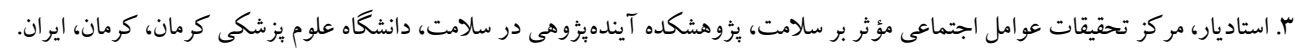 \\ كد ار كيد:

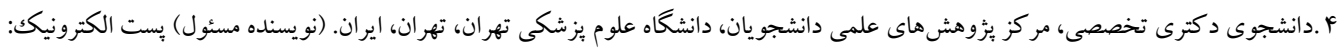

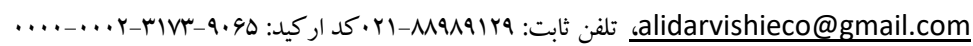

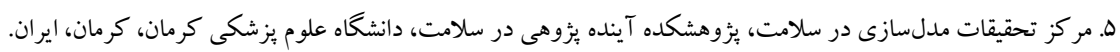

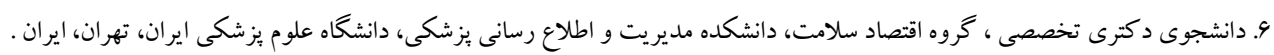

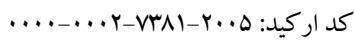

جִكيله

زمينه و هدف: تحليل و بر آورد الكوى مخارج خانوارها مىتواند به عنوان يكى از ابزارهاى مناسب جهت آكاهى بخشى به

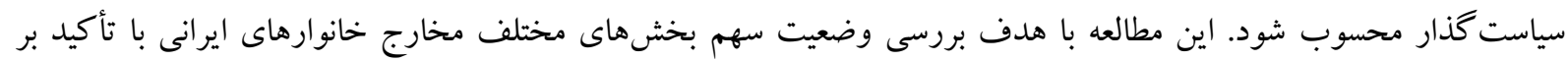
بخش بهداشت و درمان انجام شد.

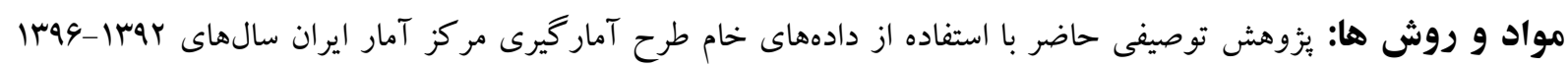

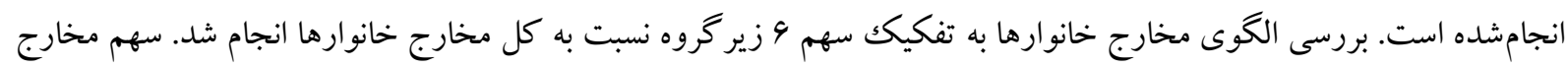
بهداشت و درمان به تفكيك بنجكك هاى درآمدى نيز در سال هاى قبل و بعد از طرح تحول سلامت بررسى شد. براى رسم

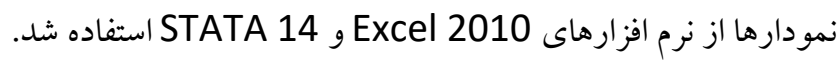
يافته ها: در خانوارهاى شهرى هزينه هاى مسكن و در خانوارهاى روستايى هزينه خوراكك و يوشاكك بيشترين سهم را در مخارج خانوار داشته است. از طرفى نيز هزينههاى آموزش و تحصيل در هر دو گروه خانوارهاى شهرى و روستايى داراى كمترين سهم در

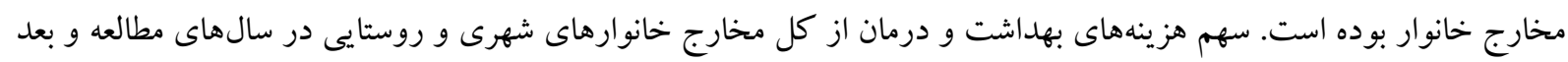
از طرح تحول سلامت با افزايش همراه بوده و در تمامى ينجك ها به جز ينجك ينجم در خانوارهاى شهرى نتايج مشابه است. نتيجه كيرى: نتايج نشان داد كه تغييراتى قابل ملاحظه در الكوى مخارج خانوارها اتفاق افتاده است. سهم بهداشت و درمان بعد از طرح تحول سلامت همجنان افزايش يافته كه نشان مى دهد اين طرح نتوانسته به خوبى در راستاى هدف حفاظت ملى اقدام نمايد.

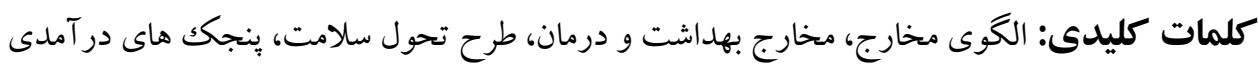

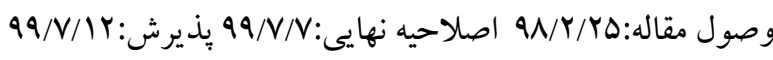


اجر ایى اين طرح نيز مى تواند شو اهد اوليه مناسبى را به همر اه

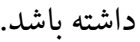

در ايران، مطالعات محدودى در زمينه بررسى الكوى مصرف خانوارهاى ايرانى بر اساس دادهاى كلان صورت

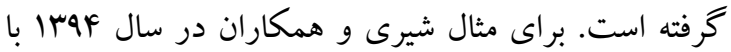
انجام مطالعهاى تحت عنوان (بررسى نقش عوامل اجتماعى و جمعيتى در تغييرات الكوى مصرف خانوارهاى شهرى و روستايى ايران) عنوان كردند كه بين مناطق شهرى و مناطق روستايى از حيث الكوى مصرف خانوار تفاوت وجود دارد

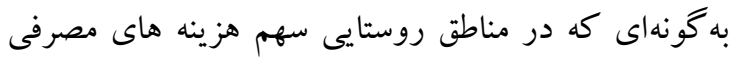
خوراك، مسكن و بهداشت و درمان از مهمترين هزينه هاى هـئه هاى مصرفى خانوارهاست. در مقابل، در مناطق شهرى، سهم

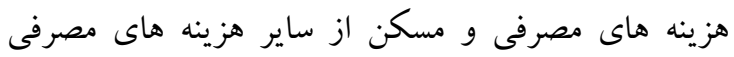

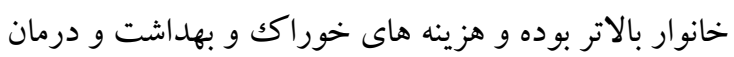
در درجه دوم اهميت قرار دارد. همجنين بر طبق نتايج اين مطالعه، هزينه ارتباطات خانوار در هر دو خانوارهاى شهرى و روستايى افزايش قابل توجهى داشته است (1).اتجزيه و تحليل رفتار بين نسلى هزينهى مصرفى خانوارهاى شهرى با

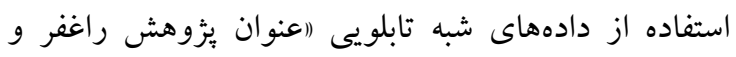
همكاران در سال سوسا بود كه با بررسى روند تغييرات هزينه مصرفى طى qج سال به اين نتيجه رسيدند كه هزينه مصرفى نسل هاى جديد در مقايسه با نسل هاى قبلى در سنين

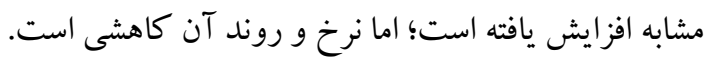

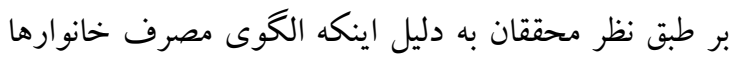

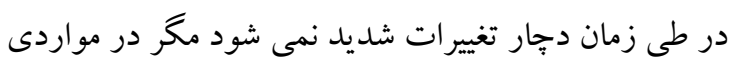
كه خانوارها جشم انداز نامعلومى را براى آينده اقتصاد كشور بيش بينى كنند، كاهش هزينه هاى مصرفى خانوار

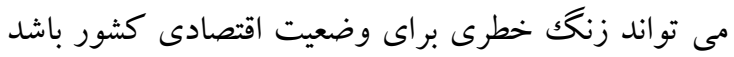

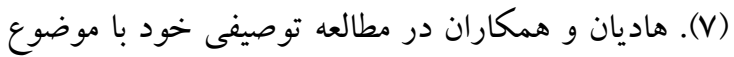
(ابابرابرى در هزينه هاى سلامت و خوراكى، مطالعه خانوارهاى شهرى و روستايى اير ان) عنوان كردند كه هم در سرى مناطق روستايى و هم در مناطق شهرى، هزينه هاى خوراك بخش قابلملاحظهاى از هزينه هاى مصرفى خانوار را به خود اختصاص مى دهد و بالا بودن اين هزينه به ويزه در
مقدمه

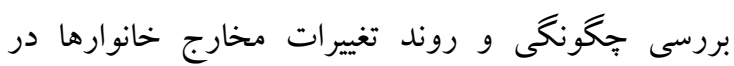

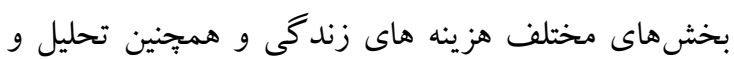

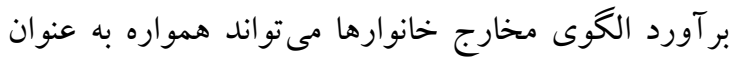

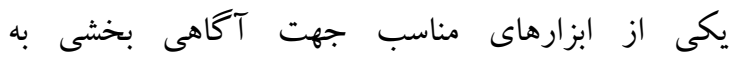
سياست گذار محسوب شود تا از وضعيت رفتارهاى مصرفى ارهاى و غير مصرفى خانوارها و تغييرات اين رفتارها در طى زمان

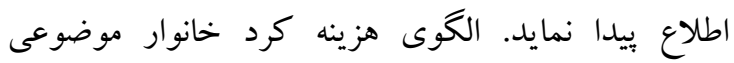
جندبعدى است كه تحقيقات مختلف با تكيه بر رويكردهاى

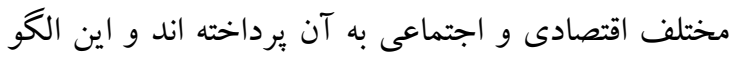
در طى جند دهه گذشته جه در مناطق شهرى و جه در

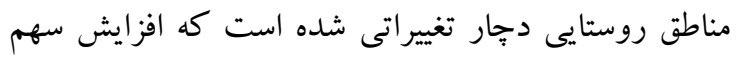
هزينه هاى مسكن، بهداشت و درمان و ارتباطات در مقابل كاهش سهم هزينه هاى خوراكك از مهمترين اين تغييرات بوده است(1). توجه به اينكه مخارج مصرفى از مهم ترين

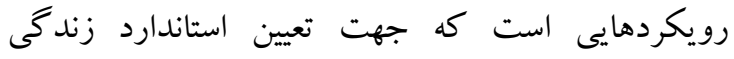

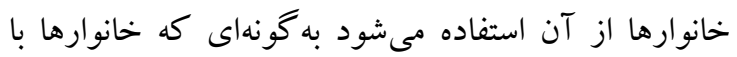

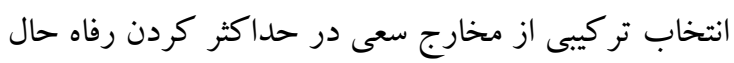

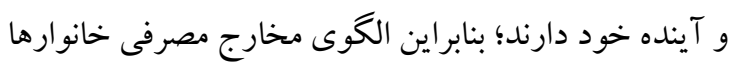
نشانكر سطح رفاهى است كه هر كشور تجربه مى كند (Y).

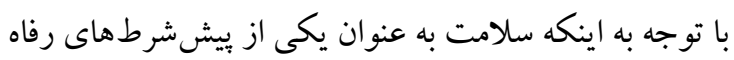

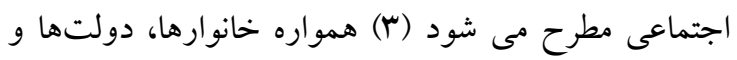

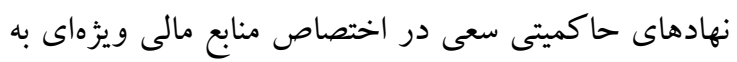

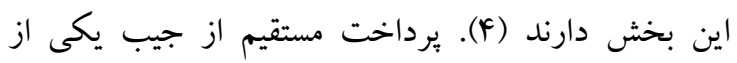

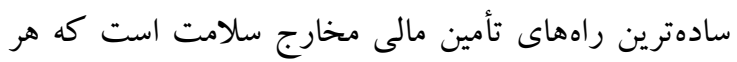

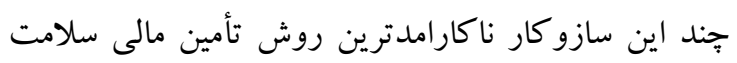

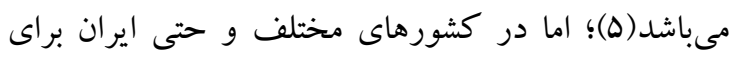
بخش قابل توجهى از خدمات از اين روش استفاده

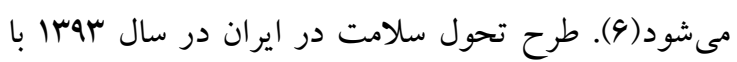
اهداف مختلفى در خصوص شاخصهاى مختلف سلامتى اجرا شد. يكى از مهمترين اهداف اين طرح كاهش سطح يرداخت از جيب خانوارها براى خدمات سلامت بود. با ليا توجه به اين، بررسى و توصيف تغييرات الكوى مخارج

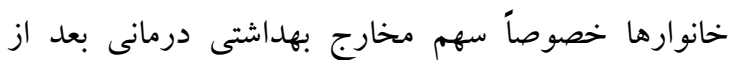


ما الكوى هذارج ذانوارهاى ايرانى...

اين طرح با هدف برآورد ميانگين هزينه هاى سالانه

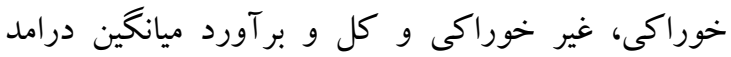

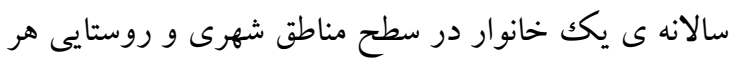

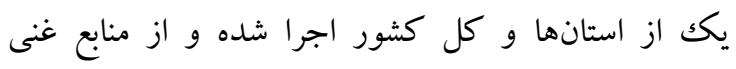

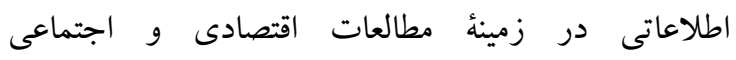
خانوارهاست. كاربردهاى اساسى و متنوع از نتايج اين آمار گيرى شامل بررسى الكوى مصرف و هزينه خانوارها، مطالعه روند مصرف كالاها و خدمات، اهميت استفاده از

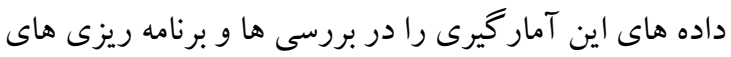
اقتصادى اجتماعى كشور نشان مى دهد. جامعه آمارى اين بُزوهش خانوارهاى كل كشور و نمونة مورد بررسى نيز از جمعيت كل كشور انتخاب شده است. زير گروه هاى سا گانه هزينه اى خانوار مورد استفاده در برد

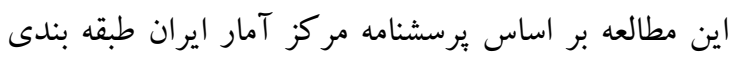

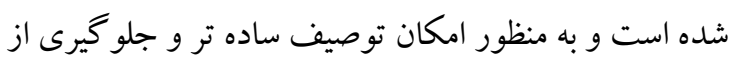

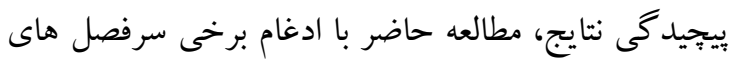

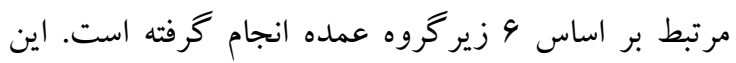

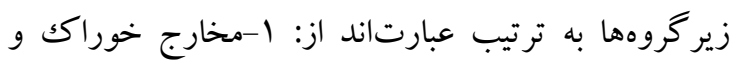
يوشاكك، r- مخارج مسكن آب و و برق و و روشنايى و و

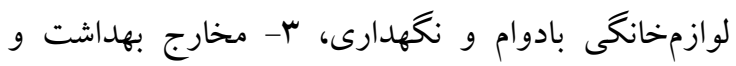

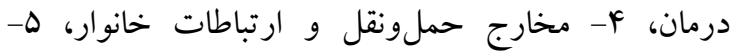
مخارج خدمات فرهنكى و تفريحات و متفرقه و 4-مخارج آموزش و تحصيل خانوار.

شاخصهايى كه در اين مطالعه به دنبال محاسبه و بررسى روند آنها در طى سالها بوديم سهم هر كدام از

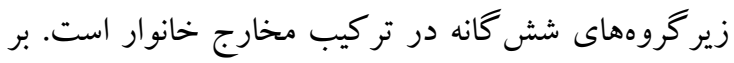

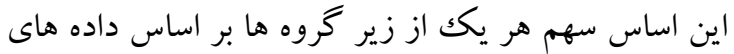
خانوارهاى شهرى و روستايى مربوط به سال هاى مختلف از

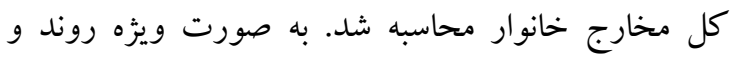
تغيير ات سهم مخارج سلامت (يرداخت از جيب) در نمونهها خصوصاً در سالهاى بعد از طرح تحول نظام سلامت ايران بررسى شد. همجنين خانوارها بر اساس ميزان مخارج مصرفى شان به يُنج طبقه اقتصادى تقسيم شدند و بررسى هاى
مناطق روستايى مى تواند موجب محدوديت هاى هزينهاى خانوار جهت رسيدگى به ساير نيازها باشد و غفلت از نيازهايى همجيون تفريح و سر گرمى بر سطح سلامت خانوار

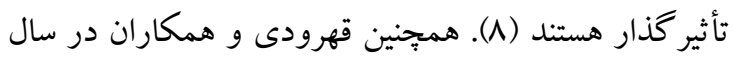

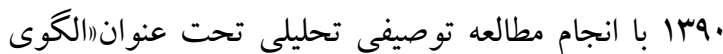
مصرف در جرخهُ زندگى خانوارهاى شهرى " به اين نتيجه رسيدند كه الكوى هزينه خانوارهاى شهرى در بخش هاى مختلف هزينه اى در طول سالهاى بررسى شده تغيير يافته

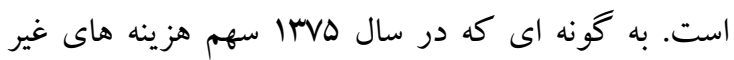

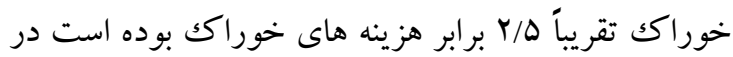

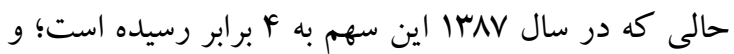
همجينين سهم هزينه هاى بهداشت و درمان افزايش يافته

(9) (9) (9) (9)

با توجه به مطالب ذكر شده و اهميت بررسى الكوى مخارج

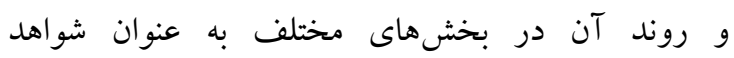

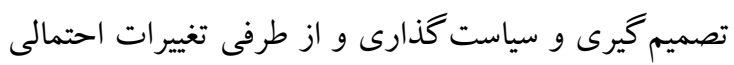
اين الكو در اثر مسائل بينالمللى و سياستهاى كلان ولان كشورى از جمله طرح تحول سلامت كه ممكن است دين

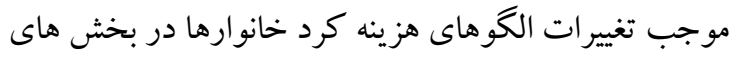
مختلف شده باشد، هدف از انجام اين مطالعه بررسى وضعيت سهم بخش هاى مختلف مخارج خانوارهاى ايرانى

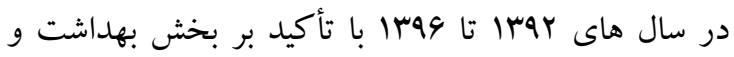

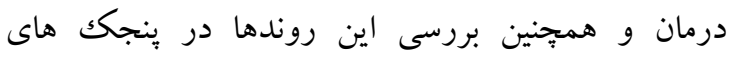

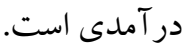

\section{مواد و روش ها}

در بززوهش توصيفى حاضر به منظور بررسى وضعيت الكوى هو

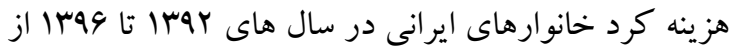
داده هاى خام طرح آمارگيرى هزينه و درآمد خانوارها مركز آمار ايران استفاده شده است كه بر روى آنها تحليل ثانويه انجام گرفت( •(1). طرح آمارگيرى از هزينه و درامد خانوارهاى شهرى و روستايى يكى از قديمىترين طرحهاى آمارگيرى اجراشده توسط مركز آمار ايران است كه با

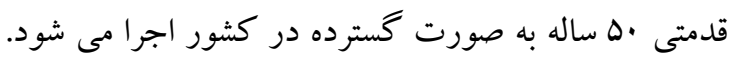


نمونه گيرى خانوارها به عنوان سطح معرف يذيرى نمونه از جامعه واقعى لحاظ شد.

يافته ها

نمودار شماره ا نشان دهنده سهم زير گروههاى شش گانه از

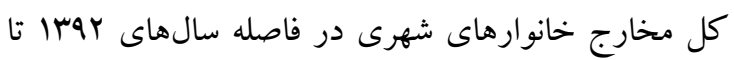

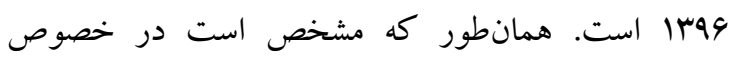
خانوارهاى شهرى هزينه هاى مسكن و كالاى باد بادوام

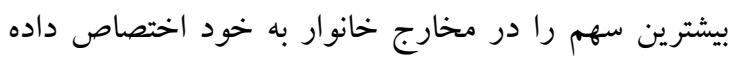
است و كمترين سهم مخارج نيز مربوط به هزينه هاى آموزش و تحصيل است. سهم هزينه هاى مسكن و كالاى

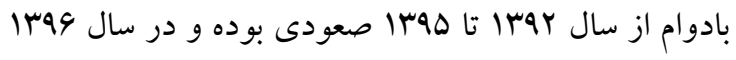
كاهش يافته است، سهم هزينه هاى خوراك و و بوشاك و و هزينه هاى آموزش و تحصيل در اين سال ها برخلاف هزينه

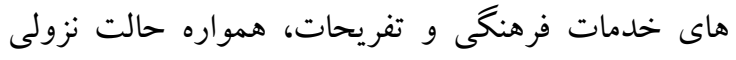

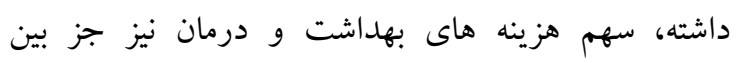

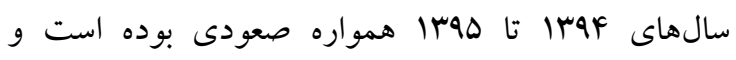

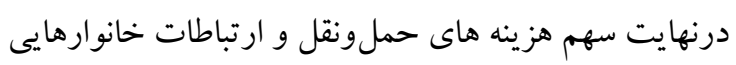

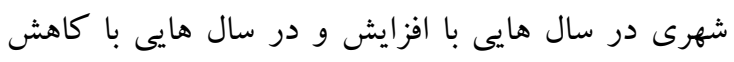

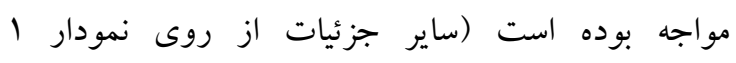

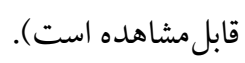

مشابه انجام شد. لازم به ذكر است كه در طرح هزينه و

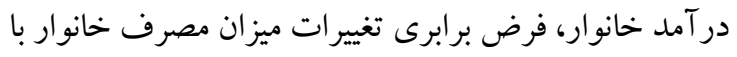
تغييرات ميزان هزينه هاى مصرفى خانوار وجود دارد و يا به بيانى ديخر مقدار هزينه هاى يولى كه خانوار براى تأمين اقلام مصرفى مختلف خود صرف مى كند حاكى از ميزان مصرف خانوار است.

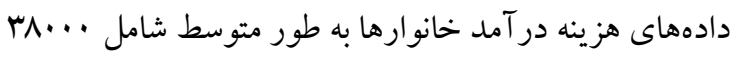

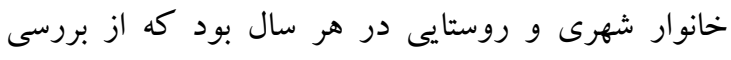

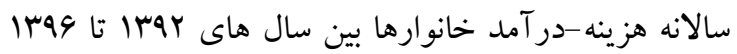

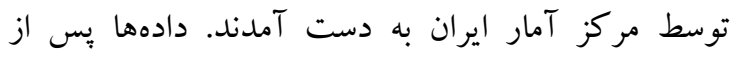

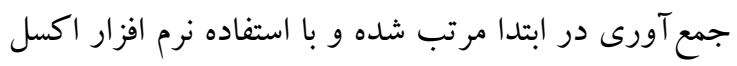

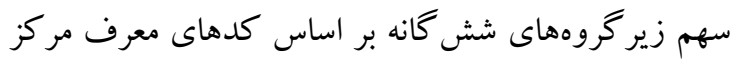

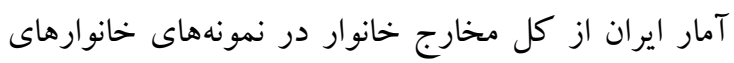

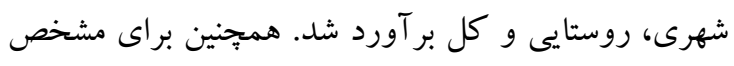

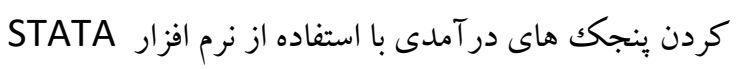

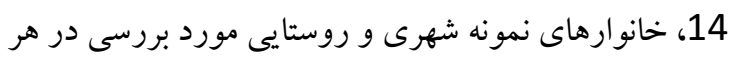
سال به ينج طبقه مختلف درآمدى تقسيم شدند. همينين جهت توصيف بهتر نتايج از نمودارهايى بدين منظور استفاده

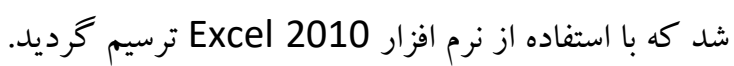

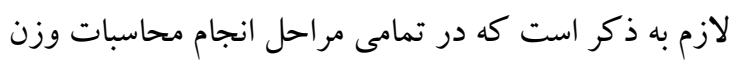




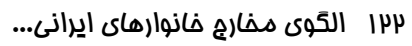

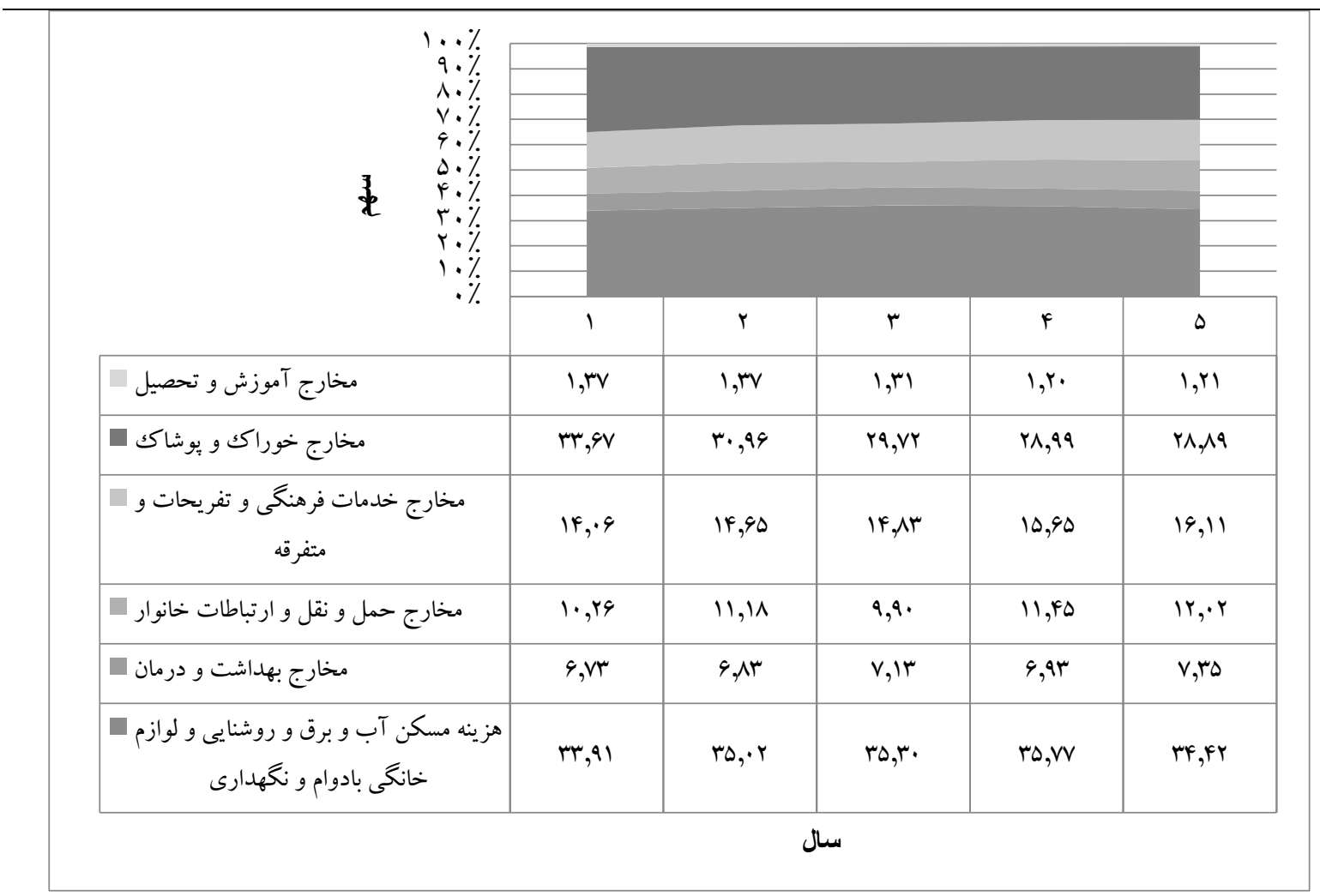

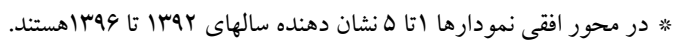

نمودار ا. نمودار روند وضعيت الكوى هز ينه كرد خانوارهاى شهرى ايران

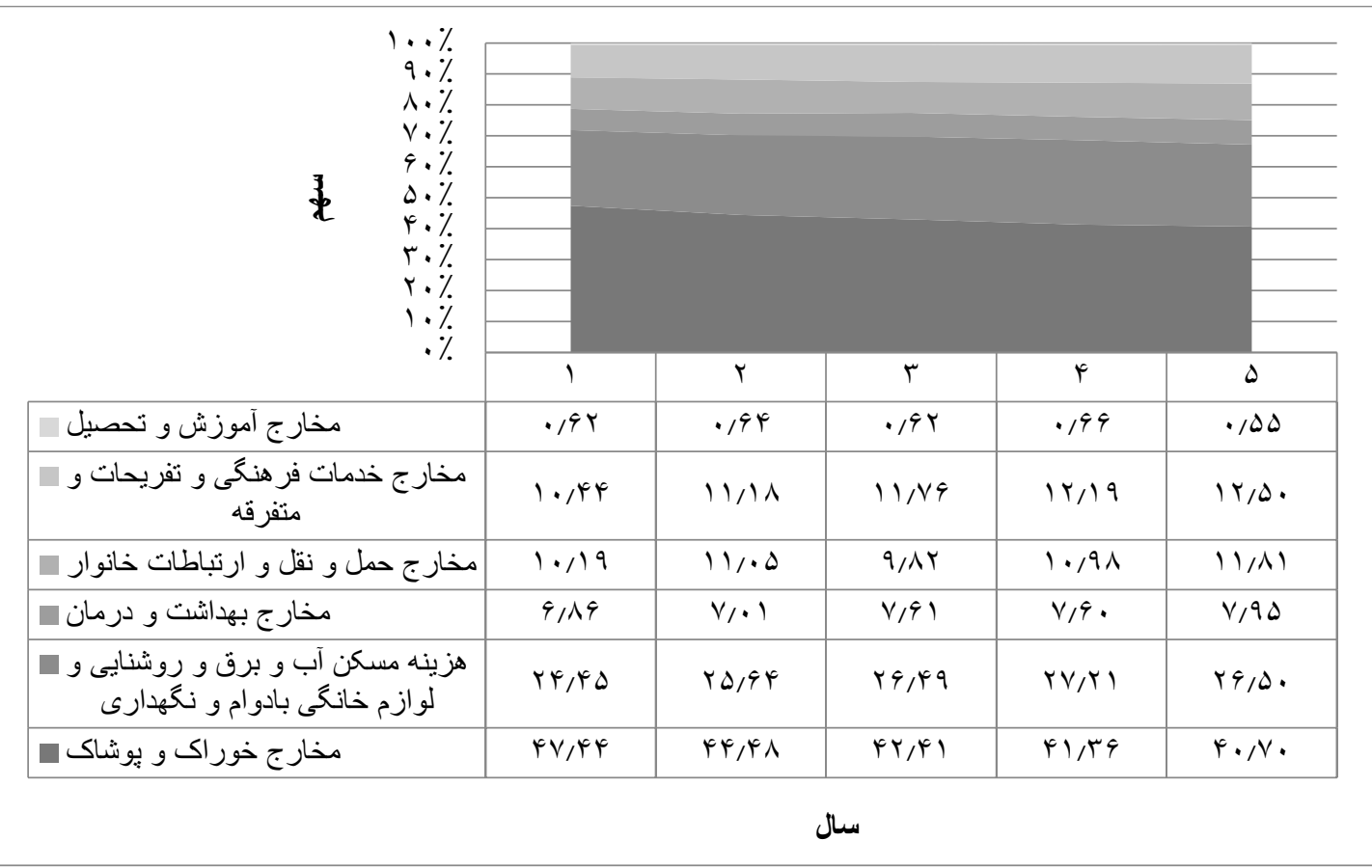

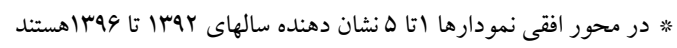
نمودار r. نمودار روند وضعيت الكوى هزينه كرد خانوارهاى روستايى ايران

هبلم علمى دانشكاه علوه دِزشكى كردستان / دوره بيست و شش / درداد و شهريور م.ع|| 
هزينه هاى حمل و نقل و ارتباطات در سال هايى با افزايش و در سال هايى با كاهش مواجه بوده است (ساير جزئيات از

$$
\text { روى نمودار قابل مشاهده است). }
$$

نمودار r نشان دهنده روند سهم مخارج بهداشت و درمان خانوارهاى روستايى و شهرى ايران در سال هاى بوسا تا

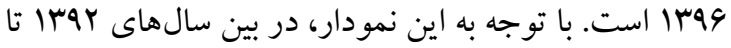
צهrا، ميزان برداخت از جيب با نوساناتى همراه بوده است؛ اما در مجموع سهم هزينه بهداشت و درمان از كل مخارج خانوارهاى شهرى و روستايى با افزايش همراه بوده و اين افزايش سهم در خانوارهاى روستايى از خانوارهاى شهرى
نمودار r نشان دهنده سهم زير گروههاى شش گانه از كل مخارج خانوارهاى روستايى در فاصله سالهاى بarا تا و 1 است. همانطور كه مشخص است در رابطه با خانوارهاى روستايى هزينه خوراكك و بوشاكك بيشترين سهم را در مخارج خانوار به خود اختصاص داده است و كمترين سهم مخارج نيز مربوط به هزينه هاى آموزش و تحصيل است. همانند خانوارهاى شهرى سهم هزينه هاى مسكن و كالاى بادوام از سال بar| تا هوسا صعودى بوده و در سال 94M كاهش يافته است. سهم هزينه هاى خوراك و يوشاكك همواره حالت نزولى و سهم هزينه هاى خدمات فرهنگى و تفريحات همواره حالت صعودى داشته است. هزينه هاى آموزش و تحصيل، بهداشت و درمان و همجينين

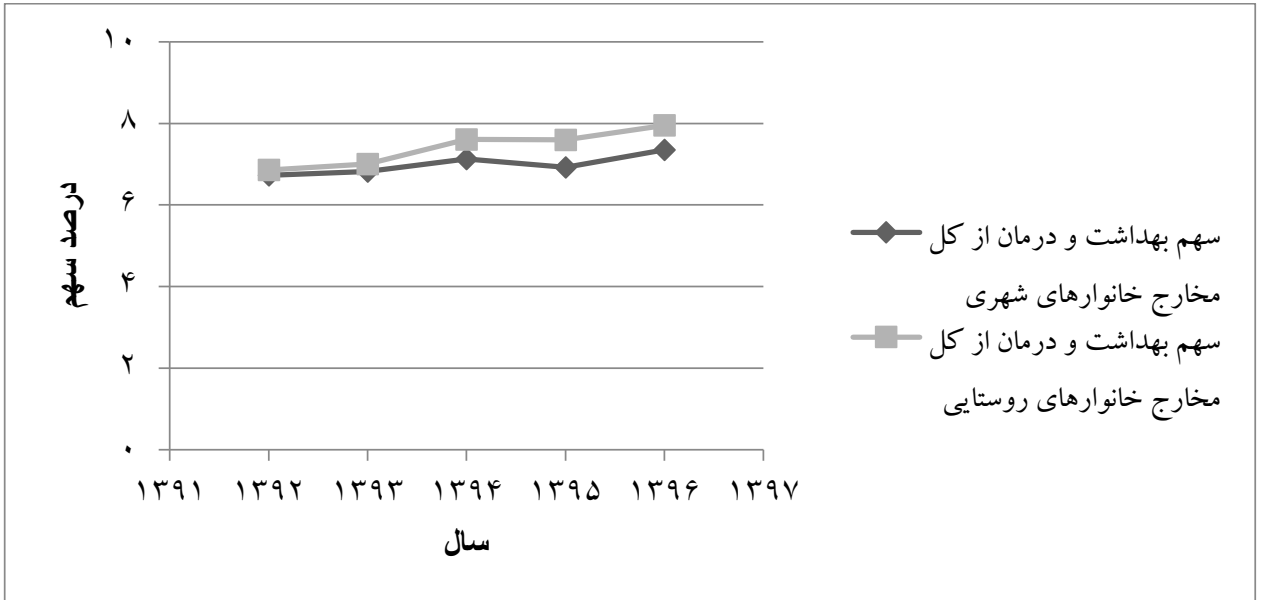

نمودار r. سهم بهداشت و درمان از مخارج كل خانوارهاى شهرى و روستايى

درآمدى، در ينجك اول مخارج بهداشت و درمان خانوارهايى شهرى در سال 99با كمتر از سال بوسا است؛ اما در ساير بنجك ها با وجود اينكه اين روند با افزايش و كاهش هايى همراه بوده است؛ اما در مجموع خانوارها در سال وهوا نسبت به سال rarا مقدار بيشترى از مخارج خود را به بهداشت و درمان اختصاص دادهاند (ساير جزئيات از روى جدول و نمودار قابل استنباط است).
جدول ا و نمودار f نشان دهنده سهم هزينه بهداشت و درمان خانوارهاى شهرى ايران از كل مخارج به تفكيك ينجك هاى درآمدى در سالهاى بوسا تا و4سا است

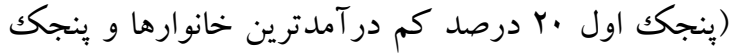

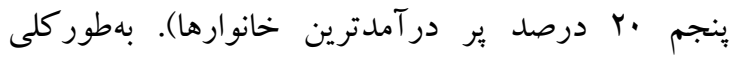

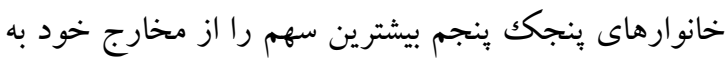
بهداشت و درمان اختصاص مىدهند و كمترين سهم مربوط به پينجك اول است. بر خلاف ينجك هاى دوم تا ينجم 


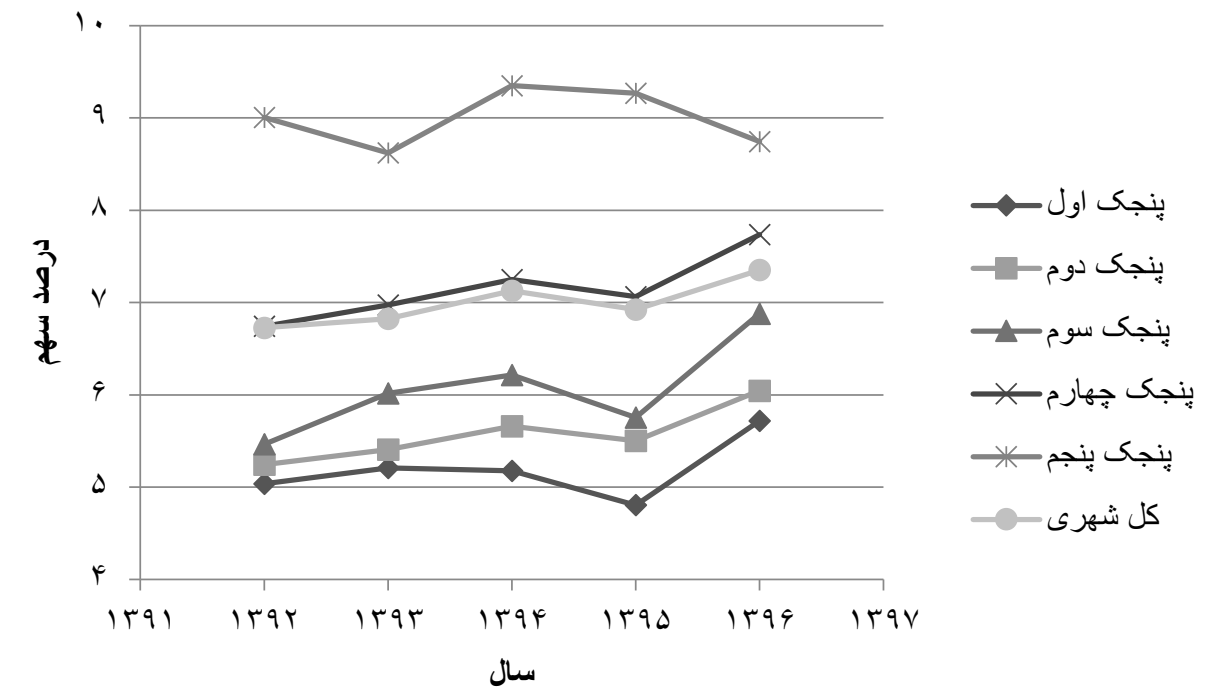

نمودار F. سهم هزينه بهداشت و درمان در ينجك هاى در آمدى خانوارهاى شهرى

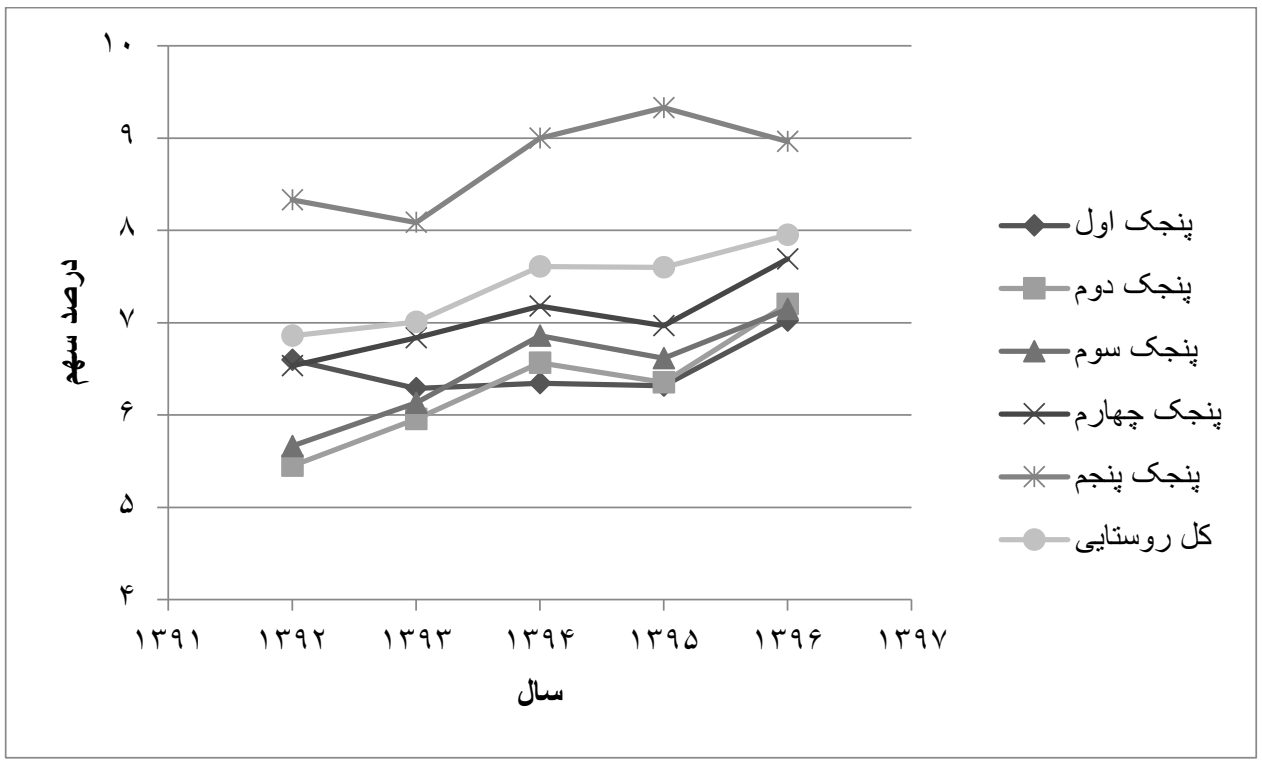

نمودار ه. سهم هزينه بهداشت و درمان در بنجكك هاى درآمدى خانوارهاى روستايى

سال بعدى متعلق خانوارهاى ينجك اول مىباشد. در كل با

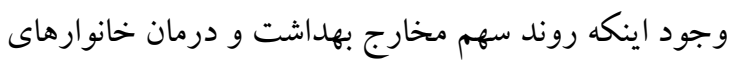
روستايى در ينجك هاى درآمدى مختلف با افزايش و كاهش هايى همراه بوده است؛ اما در مجموع خانوارها در سال وهبا نسبت به سال بوسا مقدار بيشترى از مخارج خود را به بهداشت و درمان اختصاص دادهاند (ساير جزئيات از روى نمودار قابل استنباط است).
جدول Y و نمودار ه نشان دهنده سهم هزينه بهداشت و درمان خانوارهاى روستايى ايران از كل مخارج به تفكيك ينجك هاى درآمدى در سالهاى بوسا تا و وسا است. همانند خانوارهاى شهرى به طور كلى خانوارهاى روستايى ينجك ينجم بيشترين سهم از مخارج خود را در مقايسه با بال ساير بنجك ها به بهداشت و درمان اختصاص مى دهند و كمترين سهم در دو سال اول مربوط به ينجك دوم و سه له به 
جدول ا. سهم هزينه بهداشت و درمان در ينجك هاى در آمدى خانوارهاى شهرى

\begin{tabular}{|c|c|c|c|c|c|c|}
\hline \multicolumn{6}{|c|}{ سهم هزينه بهداشت و درمان از كل مخارج خانوار } & \multirow[t]{2}{*}{ سال } \\
\hline كل & ينجاك يُجم & ينجك جهارم & ينجكك سوم & ينجك دوم & ينجك اول & \\
\hline $.9 / V Y$ & $.9 / .$. & $.9 / \mathrm{NF}^{-}$ & $. \Delta / 4 q$ & $. \Delta / Y^{\prime}$ & $. \Delta / \cdot r$ & IraY \\
\hline $.9 / A Y$ & . N/GY & $.9 / 9 \mathrm{~V}$ & $.9 / .1$ & $. \Delta / 4$ & $. \Delta / r$. & אar \\
\hline$\cdot V / I Y$ & $.9 / \% \Delta$ & $\cdot V / Y F$ & $.9 / \pi 1$ & $.0 / 94$ & $\cdot \Delta / I V$ & Iraf \\
\hline . $F / 9 Y$ & $.9 / 49$ & $.8 / .9$ & $. \Delta / V \Delta$ & $\cdot \Delta / \Delta$ & $. F / \Lambda$. & $1 r 90$ \\
\hline$\cdot v / r \Delta$ & $\cdot N / V F$ & $\cdot V / N$ & $.9 / 1 \mathrm{M}$ & .91 .4 & $\cdot \Delta / V 1$ & Irag \\
\hline
\end{tabular}

جدول r. سهم هزينه بهداشت و درمان در ينجك هاى درآمدى خانوار هاى روستايى

\begin{tabular}{|c|c|c|c|c|c|c|}
\hline \multicolumn{6}{|c|}{ سهم هزينه بهداشت و درمان از كل مخارج خانوار } & \multirow[t]{2}{*}{ سال } \\
\hline كل & ينجك ينجم & ينجك جهارم & ينجك سوم & ينجك دوم & ينج & \\
\hline $.9 / 100$ & •N/Tr & $.9 / 0 r$ & $.0 / 94$ & $\cdot \Delta / F F$ & $.9 / 09$ & IraY \\
\hline$\cdot v / \cdot \cdot$ & $\cdot \wedge / \cdot \Lambda$ & $.9 / \mathrm{Ar}$ & $.9 / 14$ & $. \Delta / 9 \Delta$ & $.9 / 41$ & rar \\
\hline$. V / 9$. & $\cdot 1 / 99$ & $\cdot V / I V$ & $.9 / 100$ & .9109 & $.9 / \mu 4$ & Irat \\
\hline$\cdot V / 9$. & $.9 / \mu r$ & $.9 / 99$ & $.9 / 91$ & $.9 / \pi \Delta$ & $.9 / 41$ & 11490 \\
\hline$\cdot V / 9 \Delta$ & . N/94 & $.0 / 99$ & $\cdot V / I F$ & $\cdot V / r$. & $\cdot V / \cdot r$ & 1599 \\
\hline
\end{tabular}

خانوارهاى شهرى و روستايى در اين سالها با افزايش همراه بوده است. به نظر مىرسد در نواحى شهرى به دليل محدوديت زمين، مهاجرت خانوارها از روستاها به شهرها براى اشتغال و دسترسى بيشتر به مراكز تفريحى و درمانى و امكانات باعث شده است هزينه هاى مسكن داراى بيشترين سهم در مخارج خانوارهاى شهرى باشد. در نقطه مقابل خانوارهاى روستايى بيشتر در آمد خود را به تهيه خوراكك و يوشاكك اختصاص داده و به نوعى درصدد رفع نيازهاى اوليه خود هستند؛ اما نكته مهم اين است كه در سال هاى بوسا تا 99rا، هزينه هاى خوراكك و يوشاكك روند نزولى و هزينه خدمات فرهنكى و تفريحات روند صعودى به خود گرفته است يعنى خانوارهاى روستايى در حال گذر از توجه صرف به نيازهاى اوليه و حركت به سمت ديخر مخارج
مطالعه توصيفى حاضر با هدف بررسى وضعيت الكوى

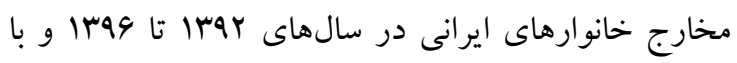
تأكيد بر روى وضعيت مخارج بهداشت و درمان انجام كرفت. اطلاعات هزينهاى همواره بـ به عنوان اهرم تصميم گيرى و سياست گذارى در حوزه هاى مختلف مورد توجه بوده است. بر بايه يافتههاى حاصل از اين مطالعه، در خانوارهاى شهرى هزينه هاى مسكن و در خانوارهاى روستايى هزينه خوراكك و بوشاكك بيشترين سهم را در مخارج خانوار داشته است. از طرفى نيز هزينه هاى آموزش لرئ و تحصيل در هر دو كروه خانوارهاى شهرى و روستايى داراى كمترين سهم در مخارج خانوار بوده است و همجنين روند آن نيز در طى سالها تغيير محسوسى نداشته است. همجنين سهم هزينه بهداشت و درمان از كل مخارج 


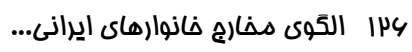

توجه به اين نكته كه در واقع زير گروه بهداشت و درمان

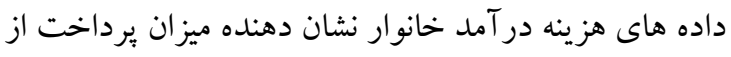
جيب خانوارها براى خدمات سلامت مى باشد. به طور كلى نتايج مطالعه نشان داد كه سهم مخارج بهداشت و درمان از

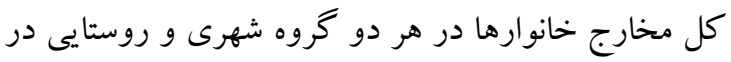
سال وهץr نسبت به سال rarا افزايش داشته است كه در اين بين سهم خانوارهاى روستايى همواره بالاتر بوده است.

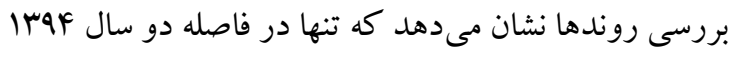

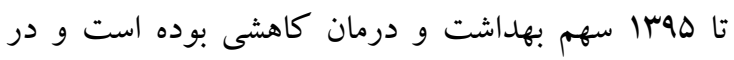
تمامى دوره هاى ديخر روند افزايش نشان مىدهد. مهم ترين سياست بكارگرفته شده در نظام سلامت در دهه اخير طرح تحول نظام سلامت بود كه اين سياست از سال سوها

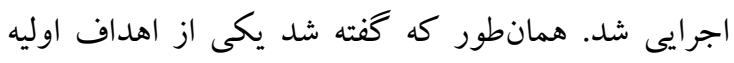
طرح كاهش درصد يرداخت از جيب خانوارها براى هزينه هاى سلامت و حفاظت مالى خانوارها در مقابل مخارج

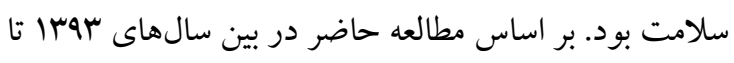

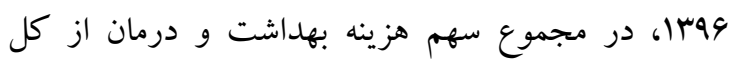

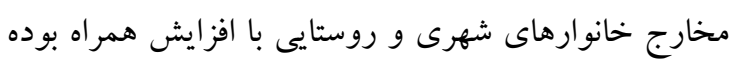

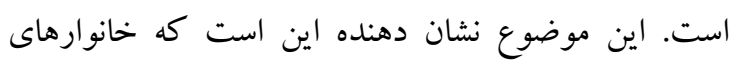
ايرانى به طور كلى در اين بازه زمانى بعد از اجراى طرح

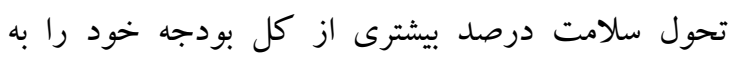

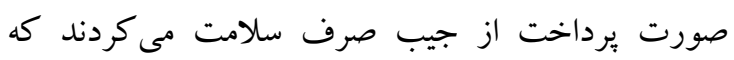

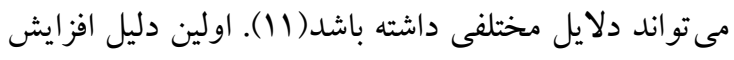

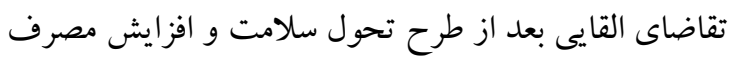

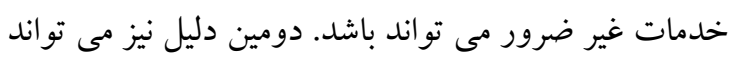
افزايش مخارج جانبى سلامت به علت تحريكى تقاضا از

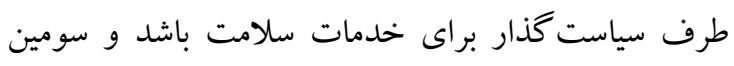
دليل را نيز مىتوان افزايش خجند برابرى تعرفه خدمات

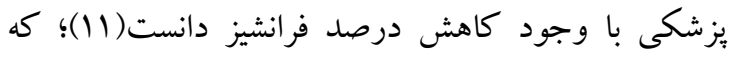
تمامى اين موارد نشان دهنده عدم كاركرد صحيح طرح تحول در راستاى هدف بيش بينى شده است. از طرف ديخر مطالعات مختلفى بيان كرده اند كه برخلاف دردئ انتظارات،

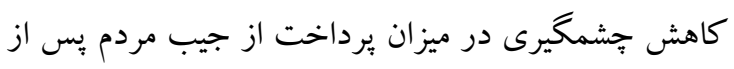

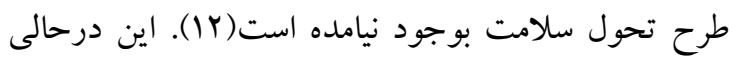

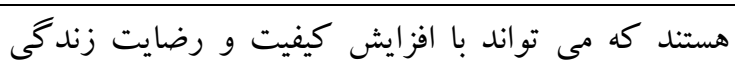

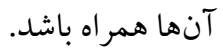
درباره روندهاى مشترك بين خانوارهاى شهرى و و مدان خانوارهاى روستايى مشاهده مىشود كه در هر دو گروره كمترين سهم هزينها مربوط به مخارج آموزش و تحصيل است كه مى تواند ناشى از آماده بودن بستر تحصيل رايخان

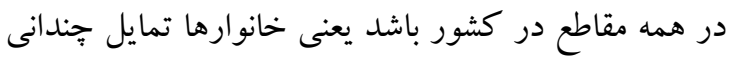

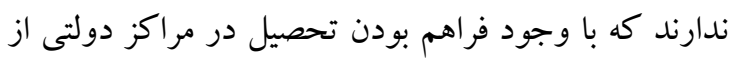
مراكز آموزشى غيردولتى استفاده كنند. از طرفى ممكن است به علت محدوديتهاى بودجه خانوار بس از مخارج

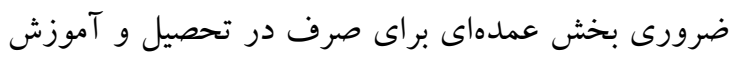

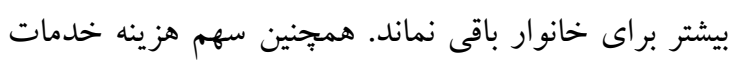
فرهنگى و تفريحات در هر دو گروه صعودى است و همان

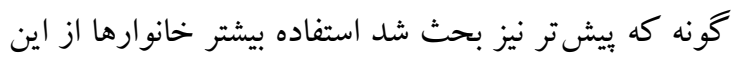

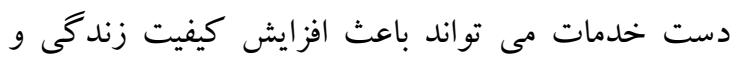

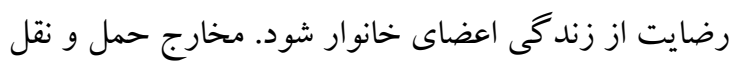

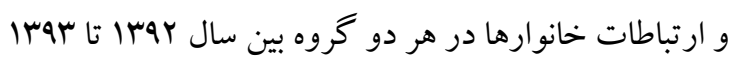

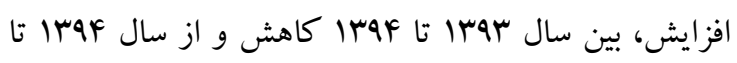

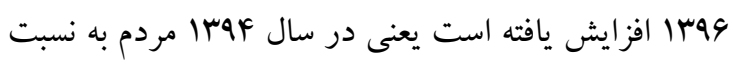

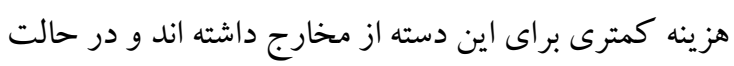

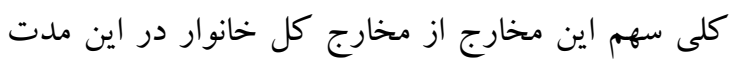

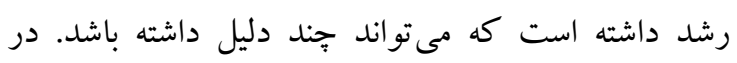

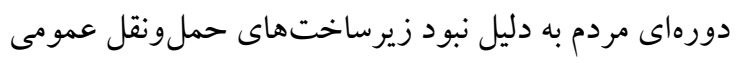

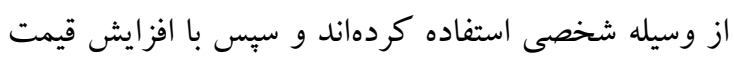

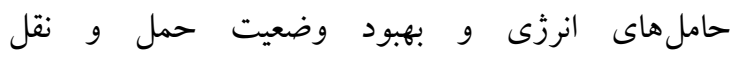
عمومى(تاكسى، اتوبوس، مترو و ...) استفاده از وسيله نقليه

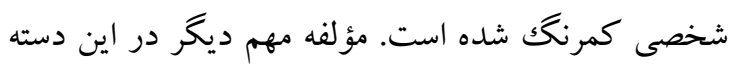
از هزينه، موضوع ارتباطات است. در سالهاى اخير با ورود

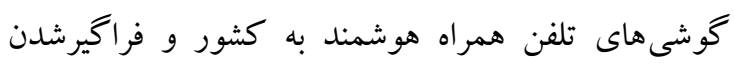
شبكه هاى اجتماعى، افراد با كاستن از ارتباطات حضورى، هون،

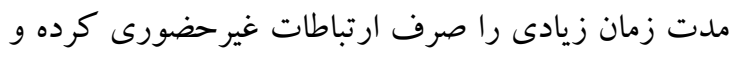
به طبع هزينه هايى را نيز براى اين موضوع متحمل مى شوند.

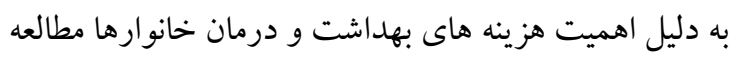

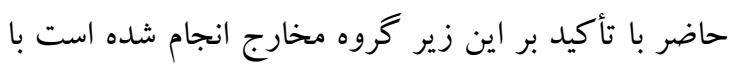




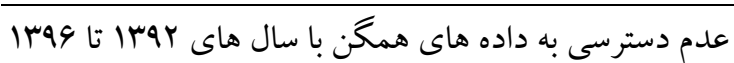

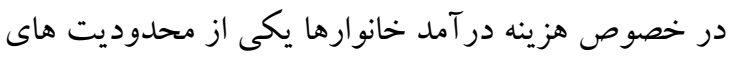

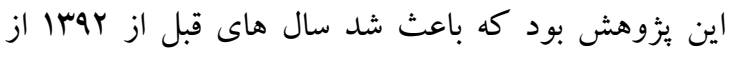

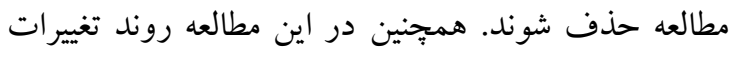

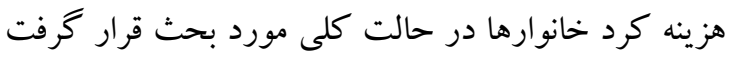
و دلايل احتمالى هر زمينه ذكر شد؛ اما بايد توجه داشت كه

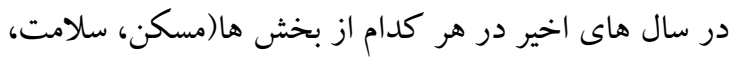
حمل و نقل، انرزى و ...) سياست هاى در كشور اجرا شده

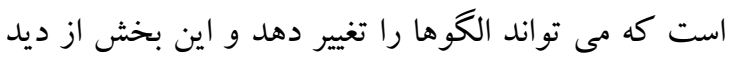

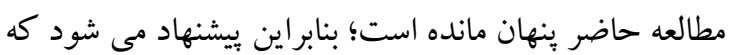

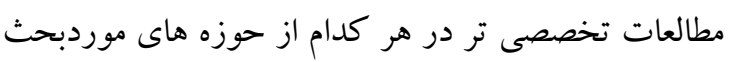

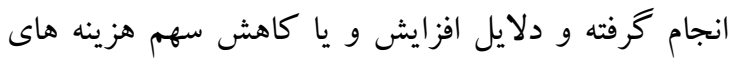

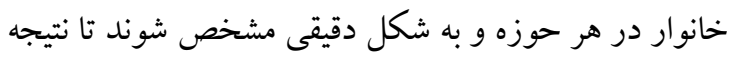

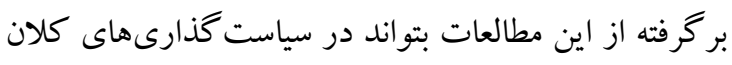
مورد استفاده تصميم گيران قرار گيرد.

\section{نتيجه كيرى}

اين مطالعه نشان داد كه بنا بر دلايل مختلف و سياستهاى

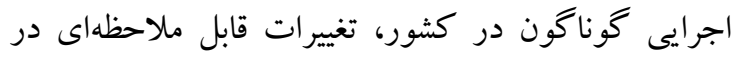

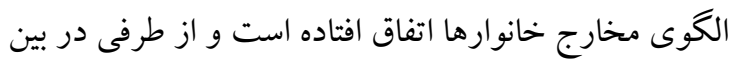
خانوارهاى شهرى و روستايى اشتراكات و تفاوتهايى از حيث نوع هزينه كرد وجود دارد. به طور كلى خانوارها

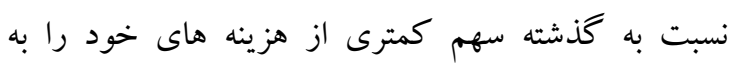
خوراكك و يوشاكى، آموزش و تحصيل اختصاص داده و در

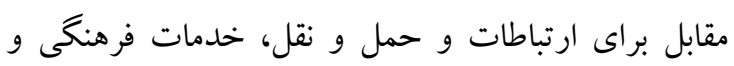

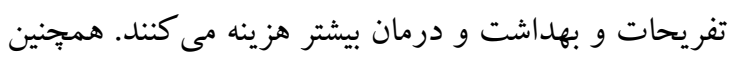

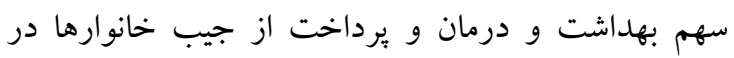

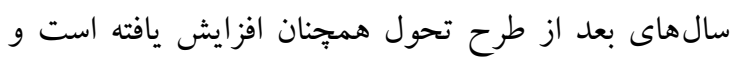

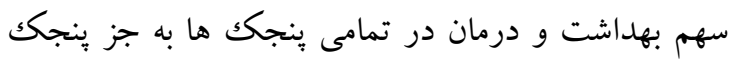

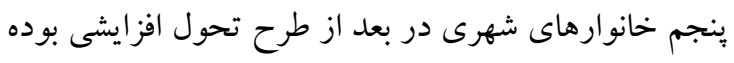
است كه نشان دهنده اين است كه اين طرح نتوانسته است به خوبى در راستاى رسيدن به هدف حفاظت ملى اقدام نمايد.
است كه اصلاحسات مشابه در نظام هاى سـلامت سـاير

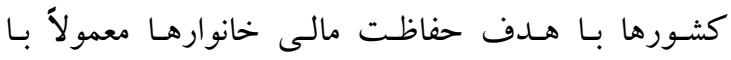
موفقيـت نسبى همراه بـوده است به طورى كه در

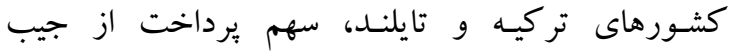
بلافاصله يس از اصلاحسات كاهش قابـل توجهى داشته

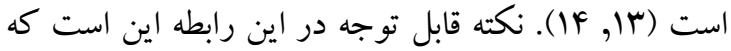

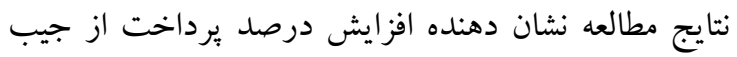

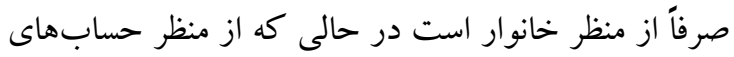

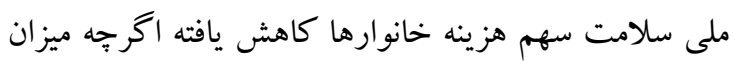
آن افزايش داشته است (ها).

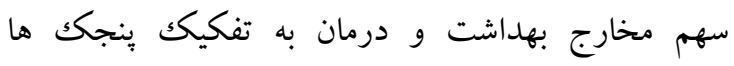

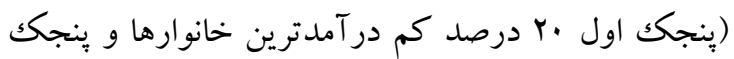

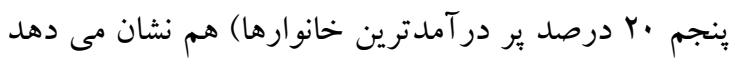

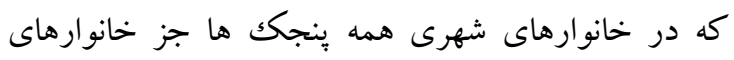

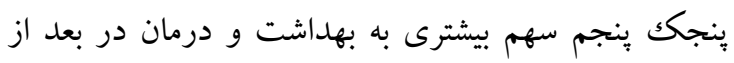

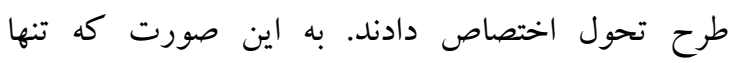
خانوارهاى پينجك ينجم سهم مخارج بهداشت و درمانشان

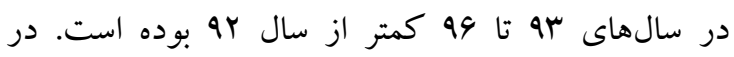

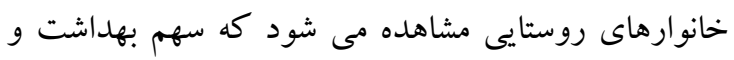
درمان در تمامى بنجكك در بعد از طرح تحول افزايشى بوده

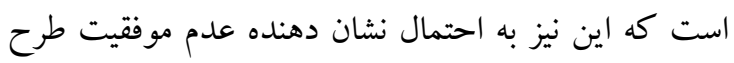
تحول در راستاى هدف حفاظت مالى است، با توجه به اينكه انتظار مىرود حداقل خانوارهاى طبقات اقتصادى ضعيفتر با كاهش سهم برداخت از جيب مواجه شوند و از اين نظر ماتر اهداف طرح تحول را محقق كنند. بيمه كردن همه خانوار بدون توجه به دهك هاى درآهدى نيز يكى ديخر از دلايل روند كند كاهش برداخت از جيب خانوارها مى تواند باشد. از اين رو به نظر مىرسد مكانيسمهاى موجود در اين خصوص در ادامه راه اجراى طرح تحول نظام سلامت، نياز

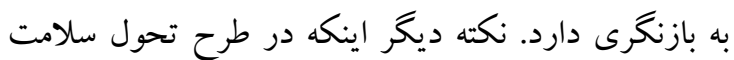
بستههاى حمايتى براى اقشار پايين كمتر مورد توجه قرار

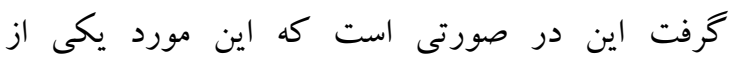
توصيههاى سازمان بهداشت جهانى هم بود(19). 


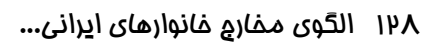

$$
\begin{aligned}
& \text { حمايتهاى مالى از اين مطالعه اعلام مىدارند. بدين وسيله }
\end{aligned}
$$

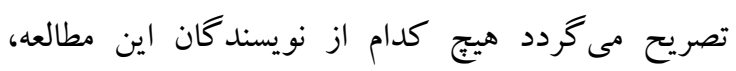

$$
\begin{aligned}
& \text { تعارض منافعى براى انتشار اين مقاله ندارند. } \\
& \text { تشكر و قدردانى } \\
& \text { بدينوسيله نويسندكان اين مقاله مراتب تشكر و قدردانى تردانى }
\end{aligned}
$$

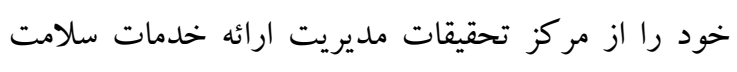

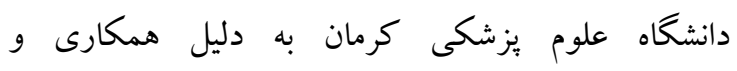

1.Shiri M, Ghazi-Tabatabaei M, Sadeghi R, Raghfar H. The study of effect of social and demographic factors on consumption pattern in rural and urban areas of Iran. J Community Dev. 2015;7(1):1-28. 2.Paytakhti-Oskouei SA Emami K. Investigating the Effect of Targeted Subsidies Plan on Consumer Patterns of Urban Households in Iran. J Eco Modelling. 2016;7(2):33-48.

3.Espina PZ, Arechavala NS. An assessment of social welfare in Spain: Territorial analysis using a synthetic welfare indicator. Soc Indic Res. 2013;111(1):1-23.

4.Mikkelsen-Lopez I, Wyss K, de Savigny D. An approach to addressing governance from a health system framework perspective. BMC Int Health Hum Rights. 2011;11(1):13.

5.Yates R. Universal health care and the removal of user fees. The Lancet. 2009;373(9680):2078-81.

6.Zakeri M, Olyaeemanesh A, Zanganeh M, Kazemian M, Rashidian A, Abouhalaj M, et al. The financing of the health system in the Islamic Republic of Iran: A National Health Account (NHA) approach. Med J Islam Repub Iran. 2015; 29 (1) :659-666.

7.Raghfar H, Babapoor M . The intergenerational analysis of urban household expenditure by using the Pseudo panel. Quarterly J AESI. 2014;3(10):177-99.

8.Hadiyan M, Ghorbani A, Ghiyasvand H, Naghdi S. Inequality in health and food expenditure, study of Iranian urban and rural households. Quarterly J Sabzevar University Med Sci. 2013;20(4):435-46.

9.Rezaei-Ghahroudi Z, Mostafavi N, Eftekhari S. Pattern of consumption in the life cycle of urban households. Soc Welfare Quarterly. 2013;13(49):243-98.

10.Iran Statistics Center. Statistical Survey; Households Income and Expenditure Survey.

Available from: http://www.amar.org.ir/Default.aspx?tabid=1507.

11. Peikanpour M, Esmaeli S, Yousefi N, Aryaeinezhad A, Rasekh H. A review of achievements and challenges of Iran's health transformation plan. Payesh. 2018; 17(5): 481-494.

12.Alvandi R, Abdi Zh, Abdalmaleki E, Mirzaei H, Goharimehr M, Ahmadnezhad E. Trend of Share of Health Expenditures on Total Household Expenditures Based on Expenditure Deciles (2009 2016. Hakim Res J. 2018;21(2):64-70.

13.Atun R, Aydın S, Chakraborty S, Sümer S, Aran M, Gürol I, et al. Universal health coverage in Turkey: enhancement of equity. The Lancet. 2013;382(9886):65-99.

14.Tangcharoensathien V, Limwattananon S, Patcharanarumol W, Thammatacharee J. Monitoring and evaluating progress towards universal health coverage in Thailand. PLoS med. 2014;11(9):e1001726.

15. Mehrolhassani M, Najafi B, Yazdi-Feyzabadi V, Haghdoost A, Abolhallaje M, Ansari M, et al. Total Health Expenditures and Proportion of Out-Of-Pocket Payments in Iranian Provinces; 20082014. Iran J Epidemiol. 2017; $12: 1-12$.

16. Mehrolhassani M, Najafi B, Yazdi Feyzabadi V, Abolhallaje M, Ramezanian M, Dehnavieh R, et al . A Review of the Health Financing Policies Towards Universal Health Coverage in Iran. Iran J Epidemiol. 2017; $12: 74-84$. 